\title{
Neospora caninum in properties in the west region of Paraná, Brazil: prevalence and risk factors
}

Neospora caninum em propriedades rurais da região Oeste do Paraná, Brasil: prevalência e fatores de risco Alessandra Snak ${ }^{1 *}$; Felipe Gustavo Garcia²; Arielle Aparecida Lara²; Hilda Fátima Jesus Pena³ ${ }^{3}$ Silvia Cristina Osaki²

${ }^{1}$ Laboratório de Doenças Parasitárias e Parasitologia, Departamento de Medicina Veterinária, Universidade do Estado de Santa Catarina - UDESC, Lages, SC, Brasil

${ }^{2}$ Laboratório de Biotecnologia, Departamento de Medicina Veterinária, Universidade Federal do Paraná - UFPR, Palotina, PR, Brasil

${ }^{3}$ Laboratório de Parasitologia, Departamento de Medicina Veterinária Preventiva e Saúde Animal, Universidade de São Paulo - USP, São Paulo, SP, Brasil

Received September 11, 2017

Accepted January 9, 2018

\begin{abstract}
Neospora caninum is a heteroxenous protozoa, whose definitive hosts are canids and intermediate hosts are herbivores, and is of great importance in cattle. The objectives of this study were to determine the prevalence of $N$. caninum in dairy cattle and dogs, to detect the presence of the protozoa at the molecular level in aborted fetuses, and to identify the risk factors associated with infection in properties in the western region of the state of Paraná. For this study, 600 bovine serum samples from 60 properties, 163 canine serum samples from 52 properties and 17 bovine fetuses from nine properties were collected. Data were collected using an epidemiological questionnaire to verify the risk factors. Serum samples were analyzed using the indirect fluorescent antibody test. Fetal tissues were analyzed using polymerase chain reaction and subsequent DNA sequencing. Of the bovine samples, $23.67 \%$ were positive for $N$. caninum. Among the canine samples, $11.66 \%$ were positive for $N$. caninum. Risk factors in cattle were history of abortion, low milk production, extensive breeding, and Jersey breed $(\mathrm{p}<0.05)$. Protozoan DNA was detected in $52.94 \%$ of the 17 fetuses and the sequencing presented high similarity with $N$. caninum.
\end{abstract}

Keywords: Abortion, neosporosis, PCR, IFAT.

\section{Resumo}

Neospora caninum é um protozoário heteroxeno, cujos hospedeiros definitivos são os canídeos e os hospedeiros intermediários são os herbívoros, apresentando maior importância em bovinos. O objetivo desse trabalho foi determinar a prevalência de $N$. caninum em bovinos leiteiros e em cães, detectar molecularmente o protozoário em fetos abortados e identificar os fatores de risco associados à infecção em propriedades da região Oeste do estado do Paraná. Para isso, foram coletadas 600 amostras de soro de bovinos provenientes de 60 propriedades, 163 amostras de soro de cáes de 52 propriedades e 17 fetos de nove propriedades. Por fim, foram coletados dados em um questionário epidemiológico para verificar os fatores de risco. As amostras de soro foram analisadas por meio da Reação de Imunofluorescência Indireta (RIFI) e os tecidos fetais foram analisados utilizando a PCR e posterior sequenciamento de DNA. Das amostras de bovinos, 23,67\% foram positivas para $N$. caninum. Entre os cães, $11,66 \%$ foram positivos. Os fatores de risco nos bovinos foram histórico de aborto, baixa produção de leite, criação extensiva e raça Jersey $(\mathrm{p}<0,05)$. Dos 17 fetos analisados, em $52,94 \%$ foi possível detectar DNA do protozoário, e o sequenciamento mostrou alta similaridade com $N$. caninum.

Palavras-chave: Abortos, neosporose, PCR, RIFI. 


\section{Introduction}

Neospora caninum is an obligate intracellular protozoan that requires two hosts to complete its cycle. Canines are its definitive hosts and dairy cattle the main intermediate hosts, but also infect sheep, goats, horses, birds, and wild animals (DUBEY \& SCHARES, 2011; GOODSWEN et al., 2013).

Canids become infected when they ingest tissues, such as placenta or fetal remains, contaminated with protozoan cysts that is at proliferative stages. Dogs exhibiting clinical signs, with diarrhea being the most common, usually associated with oocyst elimination, and neurological signs are rare (LINDSAY et al., 1999; MONNEY \& HEMPHILL, 2014; DONAHOE et al., 2015). Intermediate hosts may acquire a disease by horizontal transmission when they ingest the sporulated oocysts present in water or contaminated food (GOODSWEN et al., 2013), and vertical transmission of the protozoan, which is more important than the maintenance of the parasite in the properties. This can lead to miscarriage or the birth of congenitally infected calves. The infection can also be transmitted to future offspring. Thus, infection by this protozoan is considered one of the main causes of abortion in cattle and is responsible for innumerable losses in properties (MCALLISTER, 2016).

$N$. caninum has a wide distribution, with cases in Asia, Africa, America, Europe, and Oceania (DUBEY et al., 2007; SPILOVSKÁ et al., 2009; YU et al., 2009; PANADERO et al., 2010; REICHEL et al., 2013). Its occurrence in several countries, as well as in Brazil, varies according to the region, risk factors, and diagnostic techniques (GOODSWEN et al., 2013).

In Brazil, there are four $N$. caninum isolates from cattle: BCN/PR3 (LOCATELLI-DITTRICH et al., 2003), BCN/PR1 (LOCATELLI-DITTRICH et al., 2004), Nc-Goiás $1 \mathrm{~b}$ (GARCÍA-MELO et al., 2009) and Nc-SP1 (OLIVEIRA et al., 2017), being currently considered an important cause of abortion in cattle, bringing innumerable losses (CERQUEIRA-CEZAR et al., 2017). In recent years, the occurrence of $N$. caninum in cattle ranged from $9.1 \%$ to $97.2 \%$, and these values were found in the states of Mato Grosso do Sul and Minas Gerais, respectively (GUEDES et al., 2008; MELLO et al., 2008; CERQUEIRA-CEZAR et al., 2017). In the state of Paraná, the occurrence varies from $12 \%$ to $34.8 \%$, but most authors find results between 20 and $30 \%$ (LOCATELLI-DITTRICH et al., 2001; OGAWA et al., 2005; CERQUEIRA-CEZAR et al., 2017).

The state of Paraná in southeastern Brazil is the third largest producer of milk in Brazil, with the westernmost state being the most prominent region. Three cities (Marechal Cândido Rondon, Toledo, and Cascavel), in particular, stand out as being among the 15 largest producers in the country (IBGE, 2016).

Epidemiological studies involving pathogens that affect dairy cattle in this region are rare. Thus, the objective of this study was to determine the seroprevalence of $N$. caninum in dairy cattle and dogs, to detect molecularly the protozoan in aborted fetuses, and to identify the risk factors associated with infection in properties in the western region of Paraná.

\section{Material and Methods}

\section{Committee of ethics on animal experimentation}

This study is in accordance with the Ethical Principles of Animal Experimentation and was approved by the Commission of Ethics in the Use of Animals of the Universidade Federal do Paraná-Palotina Sector, with protocol number 50/2014.

\section{Area of study and sampling calculation}

The western region is the main dairy basin in the state of Paraná, with the cities of Marechal Cândido Rondon, Toledo, and Cascavel being the largest producers in the region (IBGE, 2016), which is the reason this region was chosen for the seroprevalence study of $N$. caninum.

Sampling was performed using the EpiInfo program (version 7.2.0.1), where an expected prevalence of $35 \%$ was used based on other studies in the state of Paraná, such as the study by Locatelli-Dittrich et al. (2008). An expected maximum error of 5\% and 95\% confidence interval and design effect (DEFF) of 1.5 , which should be used when there is no random sample collection to reduce error, were used. This resulted in a minimum of 525 samples to be collected. However, 600 animals, which were distributed in four cities of the western region of Paraná (Cascavel, Marechal Cândido Rondon, Palotina, and Toledo), were included.

The number of rural cattle farms in each city was provided by the Agricultural Defense Agency of Paraná (ADAPAR), and the number of properties where samples will be collected was evaluated, with proportional distribution shown in Table 1.

The properties in each city were randomly selected, ranging from small- to large-scale production. It was stipulated that 10 animals would be sampled from each of the 60 properties.

\section{Sample collection and application of the epidemiological questionnaire}

Cow blood samples from caudal veins were collected using 40 X $1.2 \mathrm{~mm}$ needles and $10 \mathrm{~mL}$ syringes. After collection, blood samples were stored in properly labelled test tubes without anticoagulant and kept refrigerated until processing. Data on the age, race, and abortion history of each animal were also collected.

Table 1. Distribution of farms, cattle and dogs collected in different cities of the western region of the state of Paraná, Brazil.

\begin{tabular}{ccccccc}
\hline & & \multicolumn{2}{c}{ Cattle } & & \multicolumn{2}{c}{ Dogs } \\
\cline { 3 - 4 } \cline { 6 - 7 } City & $\begin{array}{c}\text { No } \\
\text { dairies }\end{array}$ & $\begin{array}{c}\text { No of } \\
\text { collected } \\
\text { dairies }\end{array}$ & $\begin{array}{c}\text { No of } \\
\text { collected } \\
\text { animals }\end{array}$ & $\begin{array}{c}\text { No of } \\
\text { collected } \\
\text { dairies }\end{array}$ & $\begin{array}{c}\text { No of } \\
\text { collected } \\
\text { animals }\end{array}$ \\
\hline Cascavel & 1902 & 18 & 180 & 17 & 68 \\
Toledo & 2000 & 19 & 190 & 19 & 53 \\
M. C. Rondon & 1862 & 17 & 170 & 11 & 27 \\
Palotina & 591 & 6 & 60 & & 5 & 15 \\
Total & $\mathbf{6 3 5 5}$ & $\mathbf{6 0}$ & $\mathbf{6 0 0}$ & $\mathbf{5 2}$ & $\mathbf{1 6 3}$ \\
\hline
\end{tabular}


During the collection period, 17 bovine abortions occurred in nine properties: five in Palotina, two in Cascavel, one in Toledo and one in Marechal Cândido Rondon. Fragments of the heart, brain, and placenta of these fetuses were collected, packed in Microtubes, and stored at $-20^{\circ} \mathrm{C}$. After the collection of the fetuses, another visit was made to the farms to collect blood samples from the cows that had abortions, if they were not part of the 10 selected cows from the property. Thus, in addition to the 600 samples, eight blood samples were also collected.

Furthermore, samples from 163 dogs residing in 52 properties were collected (Table 1). Some properties did not allow collection of blood samples from dogs. Samples from the dogs were collected through the puncture of the cephalic vein or jugular vein using $20 \mathrm{X} 0.55 \mathrm{~mm}$ needles and $5 \mathrm{~mL}$ syringes. After collection, blood was stored in labelled test tubes and kept under refrigeration until processing. During collection of blood samples, data from animals such as age, sex, and race were also collected.

In the laboratory, samples were centrifuged at $1500 \mathrm{rpm}$ for $10 \mathrm{~min}$ for serum separation, after which they were stored in microtubes at $-20^{\circ} \mathrm{C}$ until processing.

Data were collected using an epidemiological questionnaire for the 60 properties to evaluate the main risk factors associated with neosporosis. The data collected included presence of dogs on the properties, contact of the dogs with the cattle, size of the herd, reproductive and herd management, milk production, breed, age and history of cattle abortion, as well as data related to dogs, such as feeding, race, age, sex, whether they were released or trapped, use of vermifuge and vaccines.

\section{Analysis of samples}

For the serological analysis of the samples, the indirect fluorescent antibody test (IFAT) was performed for the bovine and canine samples (PARÉ et al., 1995).

The IFAT slides were adsorbed with $N$. caninum strain Nc-1, from the Laboratory of Parasitology of the University of São Paulo (USP), fixed with methanol, and stored at $-20^{\circ} \mathrm{C}$.

Each serum sample was diluted with the dilution solution (0.0084 M Na2HPO4, 0.0018 M NaH2PO4, 0.146 M NaCl, and $1 \% \mathrm{BSA})$. Then, $20 \mu \mathrm{L}$ was added to each well of the immunofluorescence slide, and they were incubated for $30 \mathrm{~min}$ at $37^{\circ} \mathrm{C}$. After that, three washes were performed with a wash solution (0.0268M Na2CO3, 0.0975M NaHCO3, and 0.036M NaCl). Then, the slides were oven dried at $37^{\circ} \mathrm{C}$ and then $20 \mu \mathrm{L}$ of the anti-bovine and anti-canine IgG conjugate Sigma, incubated for $30 \mathrm{~min}$ at $37^{\circ} \mathrm{C}$, then three washes were performed using the stock solution. Then, the slide was oven dried at $37^{\circ} \mathrm{C}$. Afterwards, a coverslip was placed with two drops of buffered glycerin (50\%) and viewed under an epifluorescence microscope at a magnification of 400X (PARÉ et al., 1995).

Samples with total fluorescence of tachyzoites from the 1:100 dilution for cattle and 1:50 for dogs were considered positive, while samples that only presented with apical reaction were considered negative (ACOSTA et al., 2016; CAMILLO et al., 2010). Positive sera were then diluted in ratio two series to the final titre.
For the analysis of the fetuses, polymerase chain reaction (PCR) was performed. About $5 \mathrm{~g}$ of the collected organs (heart, brain, and placenta) were individually macerated; then, DNA extraction was performed using the commercial kit DNeasy Blood and Tissue (Qiagen). For PCR, the Nc5 region was selected as the target sequence for DNA amplification. The primers Np21/Np6 (5'-CCCAGTGCGTCCAATCCTGTA-3')/ (5'-CTCGCCAGTCAACCTACGTCTTCT-3') (MÜLLER et al., 1996) were used. The reaction was carried out with a final volume of $50 \mu \mathrm{L}$, containing $10 \mathrm{X}$ buffer, $200 \mu \mathrm{M}$ DNTP, $1.5 \mathrm{mM} \mathrm{MgCl}_{2}$, $20 \mu \mathrm{M}$ of each primer, $1.25 \mathrm{U}$ Taq DNA Polymerase, with initial denaturation at $95^{\circ} \mathrm{C}$ for $5 \mathrm{~min}, 40$ cycles at $94^{\circ} \mathrm{C}$ for $1 \mathrm{~min} / 63^{\circ} \mathrm{C}$ for $1 \mathrm{~min} / 74^{\circ} \mathrm{C}$ for $3,5 \mathrm{~min}$ and final extension at $74^{\circ} \mathrm{C}$ for $10 \mathrm{~min}$. Amplified samples were subject electrophoresis in a $1.5 \%$ agarose gel for visualization. The positive controls used were tachyzoites of the Nc-Bahia strain, and negative controls were autoclaved ultrapure water.

For the sequencing, a positive sample from each property was selected and sent to ACTGene Análise Moleculares Ltda. (Biotechnology Center, UFRGS, Porto Alegre, RS). For this, samples were sequenced by ACTGene Análises Moleculares Ltda. (Centro de Biotecnologia, UFRGS, Porto Alegre, RS, Brazil) using the automatic sequencer AB 3500 Genetic Analyzer armed with $50 \mathrm{~cm}$ capillaries and POP7 polymer (Applied Biosystems). DNA templates were labeled with 2.5 pmol of the primer Np21/Np6 and $0.5 \mu \mathrm{L}$ of BigDye Terminator v3.1 Cycle Sequencing Standart (Applied Biosystems) in a final volume of $10 \mu \mathrm{L}$. Labeling reactions were performed in a LGC XP Cycler termocycler with a initial denaturing step of $96^{\circ} \mathrm{C}$ for $3 \mathrm{~min}$ followed by 25 cycles of $96^{\circ} \mathrm{C}$ for $10 \mathrm{sec}, 55^{\circ} \mathrm{C}$ for $5 \mathrm{sec}$ and $60^{\circ} \mathrm{C}$ for $4 \mathrm{~min}$. Labeled samples were purified by isopropanol precipitation $75 \%$ followed by and $60 \%$ ethanol rinsing. Precipitated products were suspended in $10 \mu \mathrm{L}$ formamide Hi-Fi (Applied Biosystems), denatured at $95^{\circ} \mathrm{C}$ for $5 \mathrm{~min}$, ice-cooled for $5 \mathrm{~min}$ and electroinjected in the automatic sequencer. Sequencing data were collected using the software Data Collection 2 (Applied Biosystems) programmed with the following parameters: Dye Set " $Z$ "; Mobility File "KB_3500_POP7_BDTv3.mob"; BioLIMS Project "3500_Project1"; Run Module 1 "FastSeq50_POP7_50cm_cfv_100”; e Analysis Module 1 "BC-3500SR_Seq_FASTA.saz".

\section{Research of risk factors}

The seroprevalence and variables related to epidemiological questionnaire data were analyzed in the Epi Info program (version 7.2.0.1) using the chi-square test and Odds Ratio (OR), with a $5 \%$ as a significant level.

\section{Results and Discussion}

\section{Seroprevalence and risk factors}

The IFAT-based seroprevalence of $N$. caninum in dairy cattle in the western region of the State of Paraná was 23.67\% (142/600). Of the 60 properties included in this study, 80\% (48) had at least one bovine seropositive to $N$. caninum. All the properties 
surveyed in the city of Palotina were positive, whereas the cities of Cascavel, Toledo, and Marechal Cândido Rondon presented positive results in $77 \%$ of properties (Table 2).

In the studies carried out in recent years in Brazil, the occurrence of $N$. caninum in cattle ranged from 10.9 to $50.74 \%$ depending on the state, method of diagnosis, cut-off point used, main risk factors, and number of samples analyzed can also influence the results of the research (TEIXEIRA et al., 2010; AGUIAR et al., 2011; AMARAL et al., 2012; BRUHN et al., 2013).

The seroprevalence of $N$. caninum is rare in dairy cattle in Paraná. One of the reasons is the number of samples collected, which most of the time only allows the detection of occurrence and not of prevalence. The last study was by Locatelli-Dittrich et al. in 2008, who reported a seroprevalence of 33\% upon analysis of 1263 sera samples from the state of Paraná by the ELISA method. Rocha et al. (2015) evaluated 367 animals in the region of Francisco Beltrão (Southwest of Paraná) and found $35.1 \%$ of the samples to be positive, a higher percentage than the one found in the west region, which can be justified by the cutoff point of 1:50.

Camillo et al. (2010) analyzed samples from the southwest region of Paraná using the IFAT with 1:100 cutoff, and found a prevalence of $24.2 \%$. The similar seroprevalence in the southwest and west regions can be explained by geographical proximity, as well as the constant purchase or sale of cattle between the two regions.

When the properties were analyzed, Locatelli-Dittrich et al. (2008) found that $77 \%$ of the properties had at least one seropositive animal in the state of Paraná, which is similar to the results of this study in the western region of Paraná. In the state of Rio Grande do Sul, Corbellini et al. (2005) found that $93.3 \%$ of 60 properties had at least one positive animal.

Cattle titers ranged from 100 to 12800 , with most animals having titers of 800 , followed by 1600 and 400 . Only one animal had a titer of 6400 and another one had 12800. Koiwai et al. (2006) analyzed 2420 bovine sera using the IFAT for $N$. caninum and found more animals with a titer of 800 , followed by 1600 and 400 . However, other authors found a higher frequency of titers below 800 (KASHIWAZAKI et al., 2004). Titers of IgG antibodies equal to or greater than 800 are generally associated with clinical signs of the disease in cattle (DUBEY, 1999; LINDSAY et al, 1999). However, as verified by Teixeira et al. (2010), not all animals with high titers had a history of abortion, although they might have given birth to congenitally infected normal calves.

High antibody levels are associated with the reactivation and reconversion of bradyzoite into a tachyzoite, which will reach the placenta and the fetus through the circulatory system. This phase usually occurs from the fourth to the fifth month of gestation but may occur throughout the pregnancy period. This results in miscarriages or birth of congenitally infected calves. After abortion, antibody levels tend to decrease (CONRAD et al., 1993; MCALLISTER, 2016).

Of the 163 samples from dogs, 19 (11.66\%) were positive for anti- $N$. caninum antibodies. When the properties were analyzed, $28.84 \%(15 / 52)$ had at least one seropositive dog. Palotina had a higher percentage than the other three cities (Table 2).

In some experiments, dogs that ingested animal tissue with $N$. caninum cysts did not seroconvert after eliminating oocysts in the feces (LINDSAY et al., 1999; DIJKSTRA et al., 2001; SCHARES et al., 2005). In another study, which was conducted by Barber \& Trees (1998), dogs with low titers of antibodies against the protozoa became seronegative over time. Due to these factors, the actual protozoan seroprevalence in dogs may be higher than that found in this study.

Several authors have compared the seroprevalence of $N$. caninum in dogs from urban areas with those from rural areas, and this one is generally greater in the wandering dogs or domiciled in farms, fact that is related to the cycle of the parasite. As transmission to carnivores occurs through the consumption of raw meat or fetal remains with protozoan cysts, the chances of dogs becoming infected in rural areas are greater than that of dogs in urban areas (FERNANDES et al., 2004; LASRI et al., 2004; KING et al., 2012; NOGUEIRA et al., 2013).

Locatelli-Dittrich et al. (2008), analyzed 129 canine samples using IFAT from 35 properties from the entire state of Paraná and obtained $25 \%$ positive results. This percentage is considered high compared to that found in higher tham the present study.

Acosta et al. (2016) analyzed samples of 187 dogs from 30 properties in the state of Espirito Santo and found an occurrence of $11.76 \%$, which is similar to the results of this study in the west of Paraná. Nogueira et al. (2013) evaluated the prevalence of protozoa in dogs from urban and rural areas in the State of Minas Gerais and found that $11.4 \%$ of the samples had positive results: $13.78 \%$ in dogs from rural areas and $8.24 \%$ in dogs from urban areas.

The titer of the dogs measured using IFAT ranged from 50 to 800 , with a higher number of animals showing titers of $100(47.36 \%)$, followed by 50 (21.05\%) and 200 (15.79\%). Only two animals showed titers of $400(10.52 \%)$ and one animal had a titer of 800 (5.26\%). However, Nogueira et al. (2013) found anti- $N$. caninum antibodies in dogs ranging from 50 to 6400 , with a

Table 2. Occurrence of anti-Neospora caninum antibodies in cattle and dogs from dairy farms in the western region of the state of Paraná, Brazil.

\begin{tabular}{|c|c|c|c|c|c|c|c|c|c|c|c|c|}
\hline \multirow{3}{*}{ City } & \multicolumn{6}{|c|}{ Cattle } & \multicolumn{6}{|c|}{ Dogs } \\
\hline & \multicolumn{3}{|c|}{ Animals } & \multicolumn{3}{|c|}{ Dairies } & \multicolumn{3}{|c|}{ Animals } & \multicolumn{3}{|c|}{ Dairies } \\
\hline & $\mathbf{P}$ & $\mathbf{N}$ & $\%$ & $\mathbf{P}$ & $\mathbf{N}$ & $\%$ & $\mathbf{P}$ & $\mathbf{N}$ & $\%$ & $\mathbf{P}$ & $\mathbf{N}$ & $\%$ \\
\hline Cascavel & 45 & 135 & 25.00 & 14 & 4 & 77.78 & 8 & 60 & 11.76 & 5 & 12 & 29.41 \\
\hline Toledo & 40 & 150 & 21.05 & 15 & 4 & 78.95 & 5 & 48 & 9.43 & 5 & 14 & 26.31 \\
\hline M. C. Rondon & 34 & 136 & 20.00 & 13 & 4 & 76.45 & 3 & 24 & 11.11 & 2 & 9 & 18.18 \\
\hline Palotina & 23 & 37 & 38.33 & 6 & 0 & 100.00 & 3 & 12 & 20.00 & 3 & 2 & 60.00 \\
\hline Total & 142 & 458 & 23.67 & 48 & 12 & 80.00 & 19 & 144 & 11.66 & 15 & 37 & 28.84 \\
\hline
\end{tabular}

P: positive; N: negative. 
higher number of animals showing titers of 50. Acosta et al. (2016) found a greater number of dogs with titers between 800 and 1600 .

The presence of $N$. caninum seropositive dogs was not considered a risk factor for seropositivity in cattle, as it was not statistically significant (Figure 1). Other studies have also evaluated the seropositivity of dogs as a risk factor for bovine neosporosis and did not find a significant difference (GUIMARÁES et al., 2004; AGUIAR et al., 2006; LOCATELLI-DITTRICH et al., 2008; BENETTI et al., 2009). However, some authors reported a higher seroprevalence of $N$. caninum in cattle when they had contact with dogs, especially if the dogs were seropositive. Thus, the dogs could be involved in the transmission of neosporosis (PARÉ et al., 1998; WOUDA et al., 1999; SANCHEZ et al., 2003).

The insignificant difference may be an indication that the protozoan is kept in the herd by vertical transmission, not necessarily needing a definitive host (PARÉ et al., 1997; MCALLISTER,

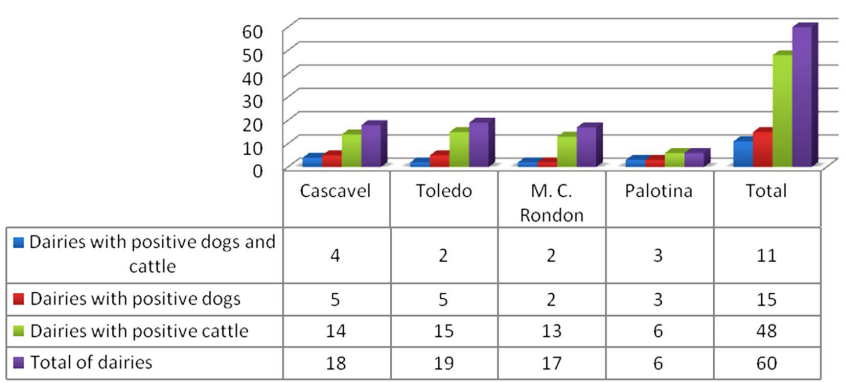

Figure 1. Correlation of the results of the properties with seropositive dogs and cattle, properties with seropositive dogs, properties with seropositive cattle, and the total data collected from properties in the west of the state of Paraná, Brazil.
2016). Another factor that must be considered is the possibility of the disease being transmitted by stray dogs or wild canids that can feed on fetal remains with the $N$. caninum bradyzoites and then disseminate the oocysts excreted in the feces through grass or water (BENETTI et al., 2009, MCALLISTER, 2016). It can be related to seroconversion, since some dogs may not seroconvert or may not be seronegative, which would influence the results of occurrence of the protozoan in dogs and its correlation with seroprevalence in bovines (BARBER \& TREES, 1998; LINDSAY et al., 1999; DIJKSTRA et al., 2001; SCHARES et al., 2005).

The risk factors related to $N$. caninum infection in dairy cattle in the western region of the state of Paraná included the following. Milk production: properties that produce 100 to 200 liters are 1.96 times more likely to have $N$. caninum than other properties. Reproductive management: properties that use artificial insemination and bull are 2.02 times more likely to have the protozoan than properties that use other reproductive management, such as bull only, or the association of bull and artificial insemination at fixed times. The type of production: cattle raised in extensive production are 1.76 times more likely to have neosporosis. A history of abortion: animals with a history of abortion have about 3.81 times more chances of having $N$. caninum. The breed Jersey are 2.18 times more likely to have $N$. caninum than other breeds (Table 3).

The main risk factors are associated with the production e reproduction profile, usually family farms with low milk production, and extensive farms, where animals raised mainly in pasture have a higher chance of contact with the protozoan.

Although the Jersey breed in this study was identified as a risk factor for $N$. caninum infection, this result reflects the sampling, since blood samples were collected from a small number of animals

Table 3. Risk factors related to the presence of anti-Neospora caninum antibodies in dairy cattle from rural properties in the western region of the state of Paraná, Brazil.

\begin{tabular}{|c|c|c|c|c|c|c|}
\hline \multicolumn{2}{|c|}{ Variables } & \multirow{2}{*}{$\frac{\text { Positive }}{7}$} & \multirow{2}{*}{$\frac{\text { Negative }}{23}$} & \multirow{2}{*}{$\frac{\%}{23.33}$} & \multirow{2}{*}{$\frac{\text { OR }}{\text { Ns }}$} & \multirow{2}{*}{$\frac{\mathbf{P}}{1.000}$} \\
\hline Milk production & $1-100 \mathrm{~L}$ & & & & & \\
\hline \multirow{10}{*}{$\begin{array}{l}\text { Reproductive manage- } \\
\text { ment }\end{array}$} & $100-200 \mathrm{~L}$ & 25 & 45 & 35.71 & $1.96(1.15-3.33)$ & 0.017 \\
\hline & $200-500 \mathrm{~L}$ & 55 & 185 & 22.92 & $\mathrm{Ns}$ & 0.799 \\
\hline & $500-1000 \mathrm{~L}$ & 32 & 118 & 21.33 & Ns & 0.507 \\
\hline & $>1000 \mathrm{~L}$ & 23 & 87 & 20.91 & Ns & 0.529 \\
\hline & Bull & 44 & 126 & 25.88 & Ns & 0.486 \\
\hline & IATF & 12 & 51 & 19.05 & Ns & 0.450 \\
\hline & IA & 37 & 111 & 25.00 & Ns & 0.742 \\
\hline & IA and IATF & 24 & 105 & 18.6 & Ns & 0.158 \\
\hline & IA and bull & 22 & 38 & 36.67 & $2,02(1,15-3,55)$ & 0.019 \\
\hline & IA, Bull and IATF & 3 & 27 & 10.00 & Ns & 0.112 \\
\hline \multirow[t]{3}{*}{ Type of production } & Extensive & 47 & 102 & 31.54 & $1.76(1.14-2.60)$ & 0.012 \\
\hline & Intensive & 29 & 90 & 24.37 & $\mathrm{Ns}$ & 0.935 \\
\hline & Semi-intensive & 66 & 266 & 19.88 & $0.62(0.42-0.91)$ & 0.019 \\
\hline Contact with dogs & & 115 & 377 & 23.37 & $\mathrm{Ns}$ & 0.814 \\
\hline Dogs pos. in daires & & 41 & 109 & 27.33 & Ns & 0.267 \\
\hline Abortion sistory & yes & 59 & 72 & 45.04 & $3.81(2.50-5.78)$ & $<0.01$ \\
\hline \multirow[t]{3}{*}{ Breed } & Holstein & 121 & 422 & 22.28 & $0.49(0.27-0.87)$ & 0.021 \\
\hline & Jersey & 20 & 32 & 38.46 & $2.18(1.20-3.95)$ & 0.014 \\
\hline & Braunvieh & 0 & 5 & 0 & $\mathrm{Ns}$ & 0.598 \\
\hline
\end{tabular}

Ns: not significant; OR: Odds Ratio; P: probability of significance; IA: artificial insemination; IATF: fixed-time artificial insemination. 
of this breed. Only two properties had Jersey and most of those were seropositive.

Semi-intensive production and Dutch breed were found to be protective factors. These results may have been influenced by the number of samples collected that did not fit these conditions, such as Jersey breed and extensive production that are risk factors.

Among the seropositive cattle (59/142), 41\% had a history of abortion, which is an important risk factor $(\mathrm{p}<0.001)$ and is the main clinical sign of neosporosis in cattle. No significant difference was found when this factor was correlated with the titers, although the majority of the animals with a history of abortion presented titers from 400 to 1600 (Table 4).

Other factors analyzed through the epidemiological questionnaire, such as presence of dogs on the property, contact with dogs, number of dogs on the farm, age of cattle, and replacement of cattle, among others, did not have significant differences.

The major risk factors for $N$. caninum infection in dogs found by other authors are as follows: age, older dogs are generally more likely to have the protozoan; feeding, dogs that consume food and/or raw meat are more likely to acquire the parasite and have contact with cattle, as they are the main intermediate hosts of N. caninum (NOGUEIRA et al., 2013).

However, in the present study, dogs did not present risk factors associated with $N$. caninum. The main factors investigated were age of the animal, contact with cattle, feeding, sex, if the dog is arrested or released, vaccination, race, use of vermifuge, and history of diseases.

\section{Aborted bovine fetus}

Seventeen dairy cattle fetuses were collected from nine properties in the region studied: four from Cascavel, two from Toledo, one from Marechal Cândido Rondon, and ten from Palotina. Of these, 52.94\% (9/17) were positive for $N$. caninum using the PCR technique and all of the samples showed a high similarity (99\%) to the protozoan by DNA sequencing.

The percentage found is considered high compared to that reported by other studies. Antoniassi et al. (2013) performed histopathological analyses of 490 fetuses and found $32.6 \%$ to be positive for $N$. caninum. Corbellini et al. (2000) found $10 \%$ of the fetuses to be positive when they analyzed tissues of 30 fetuses using the immunohistochemical technique (IHC). Orlando et al.

Table 4. Correlation of titers of seropositive cattle for Neospora caninum and history of abortion in rural properties in the western region of the state of Paraná, Brazil.

\begin{tabular}{ccccc}
\hline Titration & $\mathbf{n}^{\mathbf{o}}$ animals & $\boldsymbol{\%}$ & Abortion history & $\boldsymbol{\%}$ \\
\hline 100 & 14 & 9.86 & 3 & 21.42 \\
200 & 25 & 17.60 & 9 & 36.00 \\
400 & 29 & 20.42 & 14 & 48.27 \\
800 & 41 & 28.90 & 18 & 43.90 \\
1600 & 29 & 20.42 & 13 & 44.83 \\
3200 & 2 & 1.40 & 1 & 50.00 \\
6400 & 1 & 0.70 & 1 & 100.00 \\
12800 & 1 & 0.70 & 0 & 0 \\
Total & 142 & 100 & 59 & 41.54 \\
\hline
\end{tabular}

(2013), after analyzing tissues of 60 fetuses through PCR and IHC, found $23.33 \%$ of the samples to be positive for the protozoan. Meanwhile, analyzing the brain, lung, liver, heart and intrathoracic fluid of 30 fetuses of dairy cattle from the State of Santa Catarina, Macedo et al. (2017) found 38.8\% positives through the PCR technique, 25\% through immunohistochemistry and $26.7 \%$ through of the ELISA.

The high positivity found in the present study may be due to the technique used, since PCR is a more sensitive and more specific technique than histopathology and IHC, especially in autolysis fetuses. Another factor that may have influenced the result is the number of fetuses collected. Additionally, two properties located in Palotina had many symptomatic animals that were seropositive for $N$. caninum. The animals had abortion frames, and these fetuses were collected.

We analyzed the brains and hearts of the 17 fetuses and the placenta of only three fetuses because of the difficulty in collecting placenta. The 17 fetuses were tested using PCR: nine were positive in the brain, five in the heart, and three in the placenta. All fetuses that showed positive results in the heart and placenta also presented positive results in the brain (Table 5).

The most affected animal tissue by $N$. caninum is the central nervous system (MCALLISTER, 2016). In Brazil, there are four N. caninum isolates from bovine brain: BCN/PR3 (LOCATELLI-DITTRICH et al., 2003), BCN/PR1 (LOCATELLI-DITTRICH et al., 2004), Nc-Goias 1b (GARCÍA-MELO et al., 2009) and Nc-SP1 (OLIVEIRA et al., 2017). Thus, it is where the parasite is most commonly found through molecular techniques (SANTOS et al., 2011; ORLANDO et al. 2013, BROM et al., 2014). The protozoan can also be found in the heart, as it is one of the muscular tissues of predilection of $N$. caninum. Amaral et al. (2012) found, using PCR, a higher positivity in the heart than in the brain in fetuses coming from slaughterhouses. Therefore, it is important to evaluate and to associate the results found in both organs to decrease the number of false negatives in the diagnosis.

The placenta is an important organ that should be evaluated when possible to study the causes of abortion. It is essential to emphasize the collection of adequate material, since it is in cotyledons that most of the pathogens responsible for abortion can be found (MCALLISTER, 2016).

The gestational age with the highest occurrence (35.29\%) of the abortions was eight months; however, when the age with the highest number of fetuses positive for $N$. caninum was analyzed, it was five months (75\%), followed by four months $(66.66 \%)$, seven months (50\%), and eight months (33.33\%). These results confirm those found by other authors. in addition to having a correlation with the gestation time in which there is a greater chance of reactivation and reconversion of the bradyzoite into a tachyzoite in the maternal organism, reaching the placenta and then the fetus (ORLANDO et al., 2013; MCALLISTER, 2016).

When the fetuses were analyzed based on sex, most were females (9/14), but only $33.33 \%$ of them were positive for the protozoan studied. Of the males, $60 \%$ (3/5) were positive for $N$. caninum. It was not possible to identify the sex of three fetuses since many structures were degraded.

One animal had negative serology results for $N$. caninum, but the aborted fetus was found to be positive; this can be explained 
Table 5. Result of polymerase chain reaction of Neospora caninum from 17 bovine fetuses collected from rural properties in the western region of Paraná, Brazil.

\begin{tabular}{|c|c|c|c|c|c|c|c|}
\hline City & Dairies & Cow titration & Fetal age & Sex & PCR brain & PCR heart & PCR placenta \\
\hline \multirow[t]{4}{*}{ Cascavel } & P01 & Negative & 8 & Male & Positive & Negative & NR \\
\hline & P01 & Negative & 8 & Male & Negative & Negative & NR \\
\hline & P01 & Negative & 8 & Female & Negative & Negative & NR \\
\hline & P02 & Negative & 5 & Female & Negative & Negative & NR \\
\hline \multirow[t]{2}{*}{ Toledo } & P03 & Negative & 8 & Female & Negative & Negative & NR \\
\hline & P03 & Negative & 8 & Female & Negative & Negative & NR \\
\hline M. C. Rondon & P04 & Negative & 7 & Female & Negative & Negative & NR \\
\hline \multirow[t]{10}{*}{ Palotina } & P05 & 3200 & 5 & Female & Positive & Positive & Positive \\
\hline & P06 & 1600 & 4 & NI & Positive & Negative & Positive \\
\hline & P06 & Negative & 7 & Female & Negative & Negative & NR \\
\hline & P06 & 1600 & 8 & Female & Positive & Positive & NR \\
\hline & P07 & 800 & 7 & Female & Positive & Negative & NR \\
\hline & P07 & 1600 & 5 & NI & Positive & Positive & NR \\
\hline & P07 & 400 & 4 & NI & Positive & Positive & Positive \\
\hline & P07 & 400 & 7 & Male & Positive & Negative & NR \\
\hline & P08 & 800 & 5 & Male & Positive & Positive & NR \\
\hline & P09 & 200 & 4 & Male & Negative & Negative & NR \\
\hline
\end{tabular}

NI: unidentified; NR: unrealized.

by the false negatives that the serology technique can generate. Another animal had positive serology results, but its aborted fetus was negative for the protozoan. This can be justified by the mummified condition of the fetus, which may have degraded the $N$. caninum DNA and generated a false negative result; it is also possible that there was a different cause for the abortion.

\section{Conclusion}

$N$. caninum is widely distributed in the western region of the state of Paraná both in cattle and in dogs.

There is no correlation between the presence of seropositive dogs and the serology of the bovines in the same properties.

The main risk factors for neosporosis in cattle in the western region of the state of Paraná are related to family production (small, low milk production, and extensive properties). History of abortion is also an important risk factor for the disease.

No risk factors associated with $N$. caninum infection were identified in dogs from rural farms that were included in this study.

The protozoan can be commonly found in several fetal tissues, especially the brain. The occurrence of $N$. caninum DNA in aborted fetuses was greater in those aged between four and five months.

\section{References}

Acosta ICL, Centoducatte LDA, Soares HS, Marcili A, Gondim MFN, Rossi JL Jr, et al. Occurrence of Neospora caninum and Toxoplasma gondii antibodies in dogs from rural properties surrounding a biological reserve, Espirito Santo, Brazil. Rev Bras Parasitol Vet 2016; 25(4): 536539. PMid:27925068. http://dx.doi.org/10.1590/s1984-29612016075.

Aguiar DM, Cavalcante GT, Rodrigues AAR, Labruna MB, Camargo LMA, Camargo EP, et al. Prevalence of anti-Neospora caninum antibodies in cattle and dogs from Western Amazon, Brazil, in association with some possible risk factors. Vet Parasitol 2006; 142(1-2): 71-77. PMid:16857319. http://dx.doi.org/10.1016/j.vetpar.2006.06.014.

Aguiar DM, Lacerda DP, Orlandelli RC, Medina AO, Azevedo SS, Okuda LH, et al. Seroprevalence and risk factors associated to Neospora caninum in female bovines from the western São Paulo State, Brazil. Arq Inst Biol (Sao Paulo) 2011; 78(2): 183-189.

Amaral RLG, Silva LBG, Pinheiro JW Jr, Souza Neto OL, Leal CAS, Porto WJN, et al. Neospora caninum em bovinos em matadouros de Pernambuco e Alagoas. Pesq Vet Bras 2012; 32(10): 963-966. http:// dx.doi.org/10.1590/S0100-736X2012001000002.

Antoniassi NAB, Juffo GD, Santos AS, Pescador CA, Corbellini LG, Driemeier D. Causas de aborto bovino diagnosticadas no Setor de Patologia Veterinária da UFRGS de 2003 a 2011. Pesq Vet Bras 2013; 33(2): 155-160. http://dx.doi.org/10.1590/S0100-736X2013000200004.

Barber JS, Trees AJ. Naturally occurring vertical transmission of Neospora caninum in dogs. Int J Parasitol 1998; 28(1): 57-64. PMid:9504335. http://dx.doi.org/10.1016/S0020-7519(97)00171-9.

Benetti AH, Schein FB, Santos TR, Toniollo GH, Costa AJ, Mineo JR, et al. Pesquisa de anticorpos anti-Neospora caninum em bovinos leiteiros, cães e trabalhadores rurais da regiáo Sudoeste do Estado de Mato Grosso. Rev Bras Parasitol Vet 2009;18(e1 Supl1): 29-33. PMid:20040187. http:// dx.doi.org/10.4322/rbpv.018e1005.

Brom PRF, Regidor-Cerrillo J, Collantes-Fernández E, Ortega-Mora LM, Guimarães MS, Silva AC. Genetic characterisation of Neospora caninum strains from clinical samples of zebuine foetuses obtained in abattoirs in Goiás, Brazil. Vet Parasitol 2014; 204(3-4): 381-387. PMid:24893690. http://dx.doi.org/10.1016/j.vetpar.2014.05.011.

Bruhn FRP, Daher DO, Lopes E, Barbieri JM, Rocha CMBM, Guimarães AM. Factors associated with seroprevalence of Neospora caninum in dairy cattle in southeastern Brazil. Trop Anim Health Prod 2013; 45(5): $1093-$ 1098. PMid:23212838. http://dx.doi.org/10.1007/s11250-012-0330-y.

Camillo G, Cadore G, Cezar AS, Toscan G, Bräunig P, Sangioni LA, et al. Anticorpos anti-Neospora caninum em bovinos de leite do sudoeste do 
estado do Paraná. Arq Bras Med Vet Zootec 2010; 62(6): 1511-1513. http://dx.doi.org/10.1590/S0102-09352010000600033.

Cerqueira-Cézar CK, Calero-Bernal R, Dubey JP, Gennari SM. All about neosporosis in Brazil. Rev Bras Parasitol Vet 2017; 26(3): 253 279. PMid:28876360. http://dx.doi.org/10.1590/s1984-29612017045.

Conrad PA, Barr BC, Sverlow KW, Anderson M, Daft B, Kinde H, et al. In vitro isolation and characterization of a Neospora sp. from aborted bovine fetuses. Parasitology 1993; 106(3): 239-249. PMid:8488061. http://dx.doi.org/10.1017/S0031182000075065.

Corbellini LG, Driemeier D, Cruz C, Dias MM. Aborto bovino por Neospora caninum no Rio Grande do Sul. Cienc Rural 2000; 30(5): $863-$ 868. http://dx.doi.org/10.1590/S0103-84782000000500021.

Corbellini LG, Driemeier D, Smith D. Neosporose bovina: estudo de fatores de risco em 60 propriedades leiteiras no estado do Rio Grande do Sul e levantamento de causas de aborto bovino com ênfase em Neospora caninum. Acta Sci Vet 2005; 33(2): 231-232.

Dijkstra T, Eysker M, Schares G, Conraths FJ, Wouda W, Barkema H. Dogs shed Neospora caninum oocysts after ingestion of naturally infected bovine placenta but not after ingestion of colostrum spiked with Neospora caninum tachyzoites. Int J Parasitol 2001; 31(8): 747-752. PMid:11403764. http://dx.doi.org/10.1016/S0020-7519(01)00230-2.

Donahoe SL, Lindsay SA, Krockenberger M, Phalen D, Slapeta J. A review of neosporosis and pathologic findings of Neospora caninum infection in wildlife. Int J Parasitol Parasites Wildl 2015; 4(2): 216-238. PMid:25973393. http://dx.doi.org/10.1016/j.ijppaw.2015.04.002.

Dubey JP, Schares G, Ortega-Mora LM. Epidemiology and Control of Neosporosis and Neospora caninum. Clin Microbiol Rev 2007; 20(2): 323-367. PMid:17428888. http://dx.doi.org/10.1128/CMR.00031-06.

Dubey JP, Schares G. Neosporosis in animals - The last five years. Vet Parasitol 2011; 180(1-2): 90-108. PMid:21704458. http://dx.doi. org/10.1016/j.vetpar.2011.05.031.

Dubey JP. Recent advances in Neospora and neosporosis. Vet Parasitol 1999; 84(3-4): 349-367. PMid:10456423. http://dx.doi.org/10.1016/ S0304-4017(99)00044-8.

Fernandes BCTM, Gennari SM, Souza SLP, Carvalho JM, Oliveira WG, Cury MC. Prevalence of anti-Neospora caninum antibodies in dogs from urban, periurban and rural areas of the city of Uberlândia, Minas Gerais-Brazil. Vet Parasitol 2004; 123(1-2): 33-40. PMid:15265569. http://dx.doi.org/10.1016/j.vetpar.2004.05.016.

García-Melo DP, Regidor-Cerrillo J, Ortega-Mora LM, Collantes-Fernández E, Oliveira VSF, Oliveira MAP, et al. Isolation and biological characterisation of a new isolate of Neospora caninum from an asymptomatic calf in Brazil. Acta Parasitol 2009; 54(2): 180-185. http://dx.doi.org/10.2478/ s11686-009-0018-2.

Goodswen SJ, Kennedy PJ, Ellis JT. A review of the infection, genetics, and evolution of Neospora caninum: From the past to the present. Infect Genet Evol 2013; 13: 133-150. PMid:22985682. http://dx.doi.org/10.1016/j. meegid.2012.08.012.

Guedes MHP, Guimarães AM, Rocha CMBM, Hirsch C. Frequência de anticorpos anti-Neospora caninum em vacas e fetos provenientes de municípios do sul de Minas Gerais. Rev Bras Parasitol Vet 2008; 17(4): 189-194. PMid:19265576. http://dx.doi.org/10.1590/S198429612008000400004.

Guimarães JS Jr, Souza SLP, Bergamaschi DP, Gennari SM. Prevalence of Neospora caninum antibodies and factors associated with their presence in dairy cattle of the north of Paraná state, Brazil. Vet Parasitol 2004; 124(1-2): 1-8. PMid:15350656. http://dx.doi.org/10.1016/j.vetpar.2004.07.002.

Instituto Brasileiro de Geografia e Estatística - IBGE. Banco de Tabelas Estatísticas. Rio de Janeiro: SIDRA; 2016 [cited 2016 nov 16]. Available from: http://www.sidra.ibge.gov.br/

Kashiwazaki Y, Gianneechini RE, Lust M, Gil J. Seroepidemiology of neosporosis in dairy cattle in Uruguay. Vet Parasitol 2004; 120(1-2): 139144. PMid:15019151. http://dx.doi.org/10.1016/j.vetpar.2004.01.001.

King JS, Brown GK, Jenkins DJ, Ellis JT, Fleming PJ, Windsor PA, et al. Oocysts and high seroprevalence of Neospora caninum in dogs living in remote Aboriginal communities and wild dogs in Australia. Vet Parasitol 2012; 187(1-2): 85-92. PMid:22245069. http://dx.doi.org/10.1016/j. vetpar.2011.12.027.

Koiwai M, Hamaoka T, Haritani M, Shimizu S, Zeniya Y, Eto M, et al. Nationwide seroprevalence of Neospora caninum among dairy cattle in Japan. Vet Parasitol 2006; 135(2): 175-179. PMid:16207513. http:// dx.doi.org/10.1016/j.vetpar.2005.08.014.

Lasri S, De Meerschman F, Rettigner C, Focant C, Losson B. Comparison of three techniques for the serological diagnosis of Neospora caninum in the $\operatorname{dog}$ and their use for epidemiological studies. Vet Parasitol 2004; 123(1-2): 25-32. PMid:15265568. http://dx.doi.org/10.1016/j.vetpar.2004.05.025.

Lindsay DS, Upton SJ, Dubey JP. A structural study of the Neospora caninum oocyst. Int J Parasitol 1999; 29(10): 1521-1523. PMid:10608437. http://dx.doi.org/10.1016/S0020-7519(99)00121-6.

Locatelli-Dittrich R, Machado PC Jr, Fridlund-Plugge N, Richartz RRTB, Montiani-Ferreira F, Patrício LFL, et al. Determinação e correlação de anticorpos anti-Neospora caninum em bovinos e cães do Paraná, Brasil. Rev Bras Parasitol Vet 2008; 17(Supl1): 191-196. PMid:20059847.

Locatelli-Dittrich R, Richartz RR, Joineau ME, Pinckney RD, Sousa RS, Leite LC, et al. Isolation of Neospora caninum from a blind calf in Paraná, southern Brazil. Vet Rec 2003; 153(12):366-367. PMid:14533770. http:// dx.doi.org/10.1136/vr.153.12.366.

Locatelli-Dittrich R, Soccol VT, Richartz RRTB, Gasino-Joineau ME, van der Vinne R, Pinckney RD. Isolamento de Neospora caninum de feto bovino de rebanho leiteiro no Paraná. Rev Bras Parasitol Vet 2004; 13(3): 103-109.

Locatelli-Dittrich R, Soccol VT, Richartz RRTB, Gasino-Joineau ME, Vinne R, Pinckney RD. Serological Diagnosis of Neosporosis in a Herd of Dairy Cattle in Southern Brazil. J Parasitol 2001; 87(6): 1493-1494. PMid:11780849. http://dx.doi.org/10.1645/0022-3395(2001)087[1493:SD ONIA]2.0.CO;2.

Macedo CAB, Macedo MFSB, Miura AC, Taroda A, Cardim ST, Innes EA, et al. Occurrence of abortions induced by Neospora caninum in dary cattle from Santa Catarina, Southern Brazil. Rev Bras Parasitol Vet 2017; 26(3): 292-298. PMid:28977243. http://dx.doi.org/10.1590/ s1984-29612017051.

McAllister MM. Diagnosis and Control of Bovine Neosporosis. Vet Clin North Am Food Anim Pract 2016; 32(2): 443-463. PMid:27161392. http://dx.doi.org/10.1016/j.cvfa.2016.01.012.

Mello RC, Andreotti R, Barros JC, Tomich RGP, Mello AKM, Campolim AI, et al. Levantamento epidemiológico de Neospora caninum em bovinos de assentamentos rurais em Corumbá, MS. Rev Bras Parasitol Vet 2008; 17(Supl 1): 311-316. PMid:20059867.

Monney T, Hemphill A. Vaccines against neosporosis: what can we learn from the past studies? Exp Parasitol 2014; 140: 52-70. PMid:24602874. http://dx.doi.org/10.1016/j.exppara.2014.02.015. 
Müller N, Zimmermann V, Hentrich B, Gottstein B. Diagnosis of Neospora caninum and Toxoplasma gondii Infection by PCR and DNA Hybridization Immunoassay. J Clin Microbiol 1996; 34(11): 2850-2852. PMid:8897199.

Nogueira CI, Mesquita LP, Abreu CC, Nakagaki KY, Seixas JN, Bezerra OS, et al. Risk factors associated with seroprevalence of Neospora caninum in dogs from urban and rural areas of milk and coffee production in Minas Gerais state, Brazil. Epidemiol Infect 2013; 141(11): 2286-2293. PMid:23419686. http://dx.doi.org/10.1017/S0950268813000162.

Ogawa L, Freire RL, Vidotto O, Gondim LFP, Navarro IT. Occurrence of antibodies to Neospora caninum and Toxoplasma gondii in dairy cattle from the northern region of the Paraná State, Brazil. Arq Bras Med Vet Zootec 2005; 57(3): 312-316. http://dx.doi.org/10.1590/S010209352005000300006 .

Oliveira S, Soares RM, Aizawa J, Soares HS, Chiebao DP, Ortega-Mora $\mathrm{LM}$, et al. Isolation and biological and molecular characterization of Neospora caninum (NC-SP1) from a naturally infected adult asymptomatic cattle (Bos taurus) in the state of São Paulo, Brazil. Parasitology 2017; 144(6): 707711. PMid:28073388. http://dx.doi.org/10.1017/S0031182016002481.

Orlando DR, Costa RC, Soares BA, Oliveira NSC, Nascimento LC, Peconick AP, et al. Abortos por Neospora caninum em bovinos do sul de Minas Gerais. Pesq Vet Bras 2013; 33(11): 1332-1338. http://dx.doi. org/10.1590/S0100-736X2013001100008.

Panadero R, Painceira A, López C, Vázquez L, Paz A, Díaz P, et al. Seroprevalence of Toxoplasma gondii and Neospora caninum in wild and domestic ruminants sharing pastures in Galicia (Northwest Spain). Res Vet Sci 2010; 88(1): 111-115. PMid:19482324. http://dx.doi.org/10.1016/j. rvsc.2009.05.010.

Paré J, Fecteau G, Fortin M, Marsolais G. Seroepidemiologic study of Neospora caninum in dairy herds. J Am Vet Med Assoc 1998; 213(11): 1595-1598. PMid:9838960.

Paré J, Hietala SK, Thurmond MC. Interpretation of an indirect fluorescent antibody test for diagnosis of Neospora sp. infection in cattle. J Vet Diagn Invest 1995; 7(2): 273-275. PMid:7619917. http://dx.doi.org/10.1177 $/ 104063879500700222$.

Paré J, Thurmond MC, Hietala SK. Neospora caninum antibodies in cows during pregnancy as a predictor of congenital infection and abortion. J Parasitol 1997; 83(1): 82-87. PMid:9057701. http://dx.doi. org/10.2307/3284321.

Reichel MP, Ayanegui-Alcérreca MA, Gondim LF, Ellis JT. What is the global economic impact of Neospora caninum in cattle - The billion dollar question. Int J Parasitol 2013; 43(2): 133-142. PMid:23246675. http:// dx.doi.org/10.1016/j.ijpara.2012.10.022.

Rocha JX, Pivoto FL, Aires AR, Rocha RX, Ferreira AGT, Leal MLR. Levantamento sorológico de Neospora caninun em vacas da raça holandesa da microrregiáo de Francisco Beltrão. Vet Zootec 2015; 22(3): 396-399.

Sánchez GF, Morales SE, Martínez MJ, Trigo JF. Determination and correlation of anti-Neospora caninum antibodies in dogs and cattle from Mexico. Can J Vet Res 2003; 67(2): 142-145. PMid:12760481.

Santos DS, Andrade MP, Varaschin MS, Guimarães AM, Hirsch C. Neospora caninum in bovine fetuses of Minas Gerais, Brazil: genetic characteristics of rDNA. Rev Bras Parasitol Vet 2011; 20(4): 281-288. PMid:22166381. http://dx.doi.org/10.1590/S1984-29612011000400005.

Schares G, Pantchev N, Barutzki D, Heydorn A, Bauer C, Conraths F. Oocysts of, and in faeces collected from dogs in Germany. Int J Parasitol 2005; 35(14): 1525-1537. PMid:16197949. http://dx.doi.org/10.1016/j. ijpara.2005.08.008.

Spilovská S, Reiterová K, Kovácová D, Bobáková M, Dubinsky P. The first finding of Neospora caninum and the occurrence of other abortifacient agents in sheep in Slovakia. Vet Parasitol 2009; 164(2-4): 320-323. PMid:19540672. http://dx.doi.org/10.1016/j.vetpar.2009.05.020.

Teixeira WC, Uzêda RS, Gondim LFP, Silva MIS, Pereira HM, Alves LC, et al. Prevalência de anticorpos anti Neospora Caninum (Apicomplexa: Sarcocystidae) em bovinos leiteiros de propriedades rurais em três microrregióes no estado do Maranhão. Pesq Vet Bras 2010; 30(9): 729734. http://dx.doi.org/10.1590/S0100-736X2010000900004.

Wouda W, Dijkstra T, Kramer AMH, van Maanen C, Brinkhof JMA. Seroepidemiological evidence for a relationship between Neospora caninum infections in dogs and cattle. Int J Parasitol 1999; 29(10): 1677-1682. PMid:10608454. http://dx.doi.org/10.1016/S0020-7519(99)00105-8.

Yu X, Chen N, Hu D, Zhang W, Li X, Wang B, et al. Detection of Neospora caninum from Farm-Bred Young Blue Foxes (Alopex lagopus) in China. J Vet Med Sci 2009; 71(1): 113-115. PMid:19194087. http:// dx.doi.org/10.1292/jvms.71.113. 